\title{
周期的軸力を受ける薄肉部材の 局部振動の不安定特性
}

\author{
岡村 美好 $^{1}$ - 深沢 泰晴 2 \\ ${ }^{1}$ 正会員 工修 山梨大学助手 工学部土木環境工学科（ $\mp 400$ 山梨県甲府市武田四丁目 3-11） \\ ${ }^{2}$ 正会員 工博 山梨大学教授 工学部土木環境工学科（ $\% 400$ 山梨県甲府市武田四丁目 3-11）
}

\begin{abstract}
周期的軸力を受ける薄肉部材の局部振動の不安定特性を解明することを目的として, 両端ヒンジの箱形部 材とH形部材を対象に有限帯板法を用いた解析を行った. まず最初に, 座屈解析および固有振動解析を行い, 動的不安定の基本要因である固有振動特性および局部座屈特性について検討した. 続いて, 周期的軸力を受 ける場合の局部振動の不安定現象の解析を行い,この不安定現象を支配する諸因子の影響を明らかにすると ともに局部振動を抑えるためのダイヤフラムや補剛材の効果的な配置についても検討した.
\end{abstract}

Key Words : thin-walled member, dynamic local instability, local buckling, finite strip method

\section{1.はじめに}

動的な荷重を受けるトラス構造物の部材には, 材 端のヒンジを通じて周期的軸力が作用する.このよ うなトラス部材では, 係数励振型振動として, 部材全 体の曲げ振動が生じるばかりでなく，断面を構成す る板要素においても面外への局部的な曲げ振動が発 生する. 特に, 近年の橋梁の長大化に伴って大型化・ 軽量化が図られているトラス部材においては，この ような局部振動は板要素溶接部の疲労亀裂の発生や 騒音放射の一要因となっている.したがって, トラス 部材に生じるこのような局部振動の動的不安定性を 検討することは重要であると考えられる.

薄肉部材の局部振動の動的不安定問題については, 八巻, 永井 ${ }^{1)}$, 高橋ら 2) 5) や倉西ら6)によって報告が なされている.八巻らりは, 周期的圧縮荷重が作用す る矩形板の動的安定問題について検討を行い, 載荷 辺が単純支持の場合には各基準振動モードの間に連 成がなく主不安定領域が実際上重要な意味を持つこ と, 静的圧縮荷重の増加にともなって不安定領域の 幅は大きくなり，その傾向は座屈モードに近い基準 振動モードに対応する主不安定領域において最も顕 著であることなどを明らかにしている．また，高橋 ら 2) 5) や倉西ら ${ }^{6)}$ は, 周期的曲げモーメントを受け るプレートガーダーのウェブを対象にその面外曲げ 振動の動的不安定性について検討を行っている. し かしながら，これらはフランジに対しては限定的な 扱いをしており, プレートガーダーを構成する板要
素の連成振動を考慮した局部振動に対する不安定性 についての検討はほとんど行われていない.

本研究では, 周期的軸力が作用する薄肉部材の局 部振動の不安定特性を解明することを目的として, 代表的なトラス部材である箱形部材と $\mathrm{H}$ 形部材につ いて有限帯板法を用いた解析を行う. まず最初に, 座 屈解析および固有振動解析を行い, 局部振動の不安 定性の基本要因である局部固有振動および局部座屈 特性に係わる諸特性について検討する。これらをも とにして, 不安定領域の算定など, 局部振動の不安定 現象の解析を行い, この不安定現象を支配する諸因 子の影響特性を明らかにする. 最後にそれらの結果 を踏まえて, 局部振動を抑えるためのダイヤフラム や補剛材の効果的配置についても言及する.

\section{2. 解析方法}

図-1 に示す節線 1 と節線 2 にはさまれた帯板要素 $i$ について, 両端ヒンジを仮定すると, $x, y, z$ 軸方向 の変位成分 $u, v, w$ は Fourier 級数を適用することに より次式で表すことができる.

$$
\left\{\begin{array}{c}
u \\
v \\
w
\end{array}\right\}=\sum_{m=1}^{r}\left[\begin{array}{ccc}
\left\langle N_{p}\right\rangle C_{m} & 0 & 0 \\
0 & \left\langle N_{p}\right\rangle S_{m} & 0 \\
0 & 0 & \left\langle N_{b}\right\rangle S_{m}
\end{array}\right]\left\{\begin{array}{l}
\left\{U_{i, m}\right\} \\
\left\{V_{i, m}\right\} \\
\left\{W_{i, m}\right\}
\end{array}\right\}
$$


ここに, $r$ は Fourier 級数の採用項数であり, $\left\langle N_{p}\right\rangle$, $\left\langle N_{b}\right\rangle$ は形状関数で, $\eta=y / d$ とするとそれぞれ次式の ように表される。

$$
\begin{gathered}
\left\langle N_{p}\right\rangle=\left\langle\begin{array}{ll}
1-\eta & \eta
\end{array}\right) \\
\left\langle N_{b}\right\rangle=\left\langle\begin{array}{ll}
1-3 \eta^{2}+2 \eta^{3} & y\left(1-2 \eta+\eta^{2}\right.
\end{array}\right) \\
\left.3 \eta^{2}-2 \eta^{3} \quad y\left(\eta^{2}-\eta\right)\right\rangle
\end{gathered}
$$

$C_{m}, S_{m}$ は次式で表され，それぞれ軸方向の第 $m$ 次 モードを表している.

$$
\begin{gathered}
C_{m}=\cos \left(\frac{m \pi}{L} x\right) \\
S_{m}=\sin \left(\frac{m \pi}{L} x\right)
\end{gathered}
$$

また, $\left\{U_{i, m}\right\},\left\{V_{i, m}\right\},\left\{W_{i, m}\right\}$ は軸方向 $m$ 次モードに対 する各節線変位成分のべクトルを意味し $T$ を時間変 数とすれば次のように表される.

$$
\begin{gathered}
\left\{U_{i, m}(T)\right\}=\left\{\begin{array}{l}
u_{1, m}(T) \\
u_{2, m}(T)
\end{array}\right\} \\
\left\{V_{i, m}(T)\right\}=\left\{\begin{array}{l}
v_{1, m}(T) \\
v_{2, m}(T)
\end{array}\right\} \\
\left\{W_{i, m}(T)\right\}=\left\{\begin{array}{l}
w_{1, m}(T) \\
\theta_{1, m}(T) \\
w_{2, m}(T) \\
\theta_{2, m}(T)
\end{array}\right\}
\end{gathered}
$$

式 (1) の変位場を仮想仕事式に適用することによ り, 帯板要素に対する運動方程式を求めることがで きる．これらの局所座標系に関する各マトリクスを 全体座標系に関する量に変換し, 変位の適合条件と 力のつり合い条件にしたがってすべての帯板要素に ついて重ね合わせることにより，薄肉部材に対する 運動方程式が求められる.

部材両端がヒンジの場合には, 級数の直交性によ り運動方程式はFourier 級数の各項の運動方程式につ いて独立に解くことができる. したがって, 図-2の ような一様分布する圧縮応力を受ける両端ヒンジ薄 肉部材の構造全体に対する運動方程式は, 軸方向 $m$ 次モードについて次のように表される.

$$
\begin{aligned}
& {\left[M_{m}\right]\left\{\ddot{d}_{m}\right\}+\left(\left[K_{m}\right]-\sigma_{0}\left[K_{G m}\right]\right.} \\
& \left.-\sigma_{T} \cos \theta T\left[K_{G m}\right]\right)\left\{d_{m}\right\}=\{0\}
\end{aligned}
$$

ここに, $\sigma_{0}$ は静的応力, $\sigma_{T}, \theta$ はそれぞれ周期的応力 の振幅および円振動数であり, $\left[M_{m}\right],\left[K_{m}\right],\left[K_{G m}\right]$,

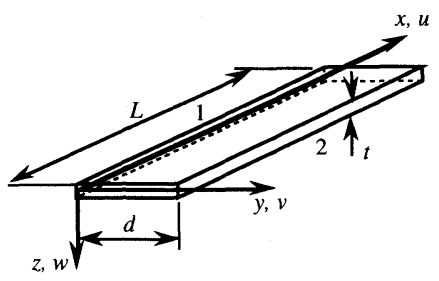

図-1 帯板要素と局所座標系

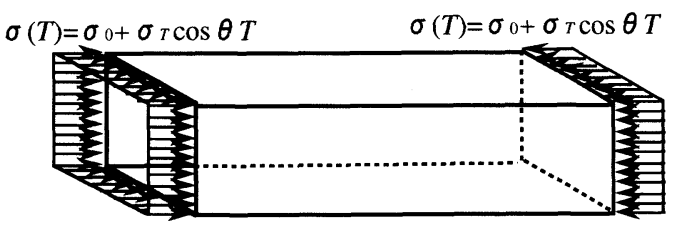

図-2 周期的軸力を受ける薄肉断面部材

$\left\{d_{m}\right\}$ はそれぞれ軸方向 $m$ 次モードに対する系全体の 質量マトリクス, 剛性マトリクス, 幾何剛性マトリク ス，および節線変位ベクトルを表す。

一様分布する静的応力 $\sigma_{0}$ が作用するときの固有振 動方程式は, 式 (9) の周期的応力 $\sigma_{T}=0$ とおくこと によりつぎのように得られる.

$$
\left[M_{m}\right]\left\{\ddot{d}_{m}\right\}+\left(\left[K_{m}\right]-\sigma_{0}\left[K_{G m}\right]\right)\left\{d_{m}\right\}=\{0\}
$$

また, 座屈方程式は, 式 (9) の慣性項を無視し, 周期 的応力 $\sigma_{T}=0$ とおくことによりつぎのように得られ る.

$$
\left(\left[K_{m}\right]-\sigma_{0}\left[K_{G m}\right]\right)\left\{d_{m}\right\}=\{0\}
$$

ここで, 式 (1) の変位場を用いた場合, 帯板要素 $i$ の軸方向 $m$ 次モードに対する質量マトリクス $\left[m_{i, m}\right]$ と 幾何剛性マトリクス $\left[k_{G i, m}\right]$ は,それぞれ次式で表され る.

$$
\begin{aligned}
& {\left[m_{i, m}\right]=\left[\begin{array}{ccc}
{\left[m_{i, m}^{U}\right]} & 0 & 0 \\
0 & {\left[m_{i, m}^{V}\right]} & 0 \\
0 & 0 & {\left[m_{i, m}^{W}\right.}
\end{array}\right]} \\
& {\left[k_{G i, m}\right]=\left[\begin{array}{ccc}
{\left[k_{G i, m}^{U}\right]} & 0 & 0 \\
0 & {\left[k_{G i, m}^{V}\right]} & 0 \\
0 & 0 & {\left[k_{G i, m}^{W}\right.}
\end{array}\right]}
\end{aligned}
$$

ここに

$$
\begin{aligned}
& {\left[m_{i, m}^{U}\right]=\rho t \int_{0}^{L} C_{m}{ }^{2} d x \int_{0}^{d}\left\langle N_{p}\right\rangle\left\{N_{p}\right\} d y} \\
& {\left[m_{i, m}^{V}\right]=\rho t \int_{0}^{L} S_{m}^{2} d x \int_{0}^{d}\left\langle N_{p}\right\rangle\left\{N_{p}\right\} d y} \\
& {\left[m_{i, m}^{W}\right]=\rho t \int_{0}^{L} S_{m}{ }^{2} d x \int_{0}^{d}\left\langle N_{b}\right\rangle\left\{N_{b}\right\} d y}
\end{aligned}
$$




$$
\begin{aligned}
& {\left[k_{G i, m}^{U}\right]=t \int_{0}^{L} \frac{d C_{m}}{d x} \frac{d C_{m}}{d x} d x \int_{0}^{d}\left\langle N_{p}\right\rangle\left\{N_{p}\right\} d y} \\
& {\left[k_{G i, m}^{V}\right]=t \int_{0}^{L} \frac{d S_{m}}{d x} \frac{d S_{m}}{d x} d x \int_{0}^{d}\left\langle N_{p}\right\rangle\left\{N_{p}\right\} d y} \\
& {\left[k_{G i, m}^{W}\right]=t \int_{0}^{L} \frac{d S_{m}}{d x} \frac{d S_{m}}{d x} d x \int_{0}^{d}\left\langle N_{b}\right\rangle\left\{N_{b}\right\} d y}
\end{aligned}
$$

式 (14), (15) において

$$
\begin{gathered}
\int_{0}^{L} C_{m}{ }^{2} d x=\int_{0}^{L} S_{m}{ }^{2} d x=\frac{L}{2} \\
\int_{0}^{L} \frac{d C_{m}}{d x} \frac{d C_{m}}{d x} d x=\int_{0}^{L} \frac{d S_{m}}{d x} \frac{d S_{m}}{d x} d x=\left(\frac{m \pi}{L}\right)^{2} \frac{L}{2}
\end{gathered}
$$

となることから，質量マトリクスと幾何剛性マトリ クスは定数係数を除いて一致する。.これにより, 式 (10), (11) より得られる固有振動と座屈の断面変形 (局部変形) モードは一致したものとなり, 式 (9) は 固有ベクトルの直交性を利用して各モードごとに分 離された運動方程式に変換することができる.

軸方向 $m$ 次モードに対する節線変位ベクトル $\left\{d_{m}\right\}$ は, 各断面変形モードに対応する固有べクトル $\left\{\phi_{m, s}\right\}(s=1,2, \cdots, n)$ と基準座標 $\xi_{m, s}$ を用いて, つ ぎのように表される.

$$
\left\{d_{m}\right\}=\sum_{s=1}^{n}\left\{\phi_{m, s}\right\} \xi_{m, s}=\left[\Phi_{m}\right]\left\{\boldsymbol{\Xi}_{m}\right\}
$$

ここに,

$$
\begin{gathered}
{\left[\Phi_{m}\right]=\left[\begin{array}{llll}
\left\{\phi_{m, 1}\right\} & \left\{\phi_{m, 2}\right\} & \cdots & \left\{\phi_{m, n}\right\}
\end{array}\right]} \\
\left\{\boldsymbol{\Xi}_{m}\right\}=\left\langle\begin{array}{llll}
\xi_{m, 1} & \xi_{m, 2} & \cdots & \xi_{m, n}
\end{array}\right\rangle^{T}
\end{gathered}
$$

式 (17) を式 (9) に代入して左から $\left[\Phi_{m}\right]^{T}$ を乗じ, 固 有ベクトルの直交性を考慮すれば，式 (9) は断面変 形モードごとに分離された運動方程式となり, 断面 変形 $s$ 次モードについてつぎのように表される.

$$
\ddot{\xi}_{m, s}+\omega_{m, s}^{2}\left(1-\frac{\sigma_{0}+\sigma_{T} \cos \theta T}{\sigma_{m, s c r}}\right) \xi_{m, s}=0
$$

ここに,

$$
\begin{gathered}
\omega_{m, s}{ }^{2}=\frac{k_{m, s}}{m_{m, s}}, \quad \sigma_{m, s c r}=\frac{k_{m, s}}{k_{G m, s}} \\
\left.m_{m, s}=\left\langle\phi_{m, s}\right\rangle M_{m}\right]\left\{\phi_{m, s}\right\} \\
k_{m, s}=\left\langle\phi_{m, s}\right\rangle\left[K_{m}\right]\left\{\phi_{m, s}\right\} \\
k_{G m, s}=\left\langle\phi_{m, s}\right\rangle\left[K_{G m}\right]\left\{\phi_{m, s}\right\}
\end{gathered}
$$

ここで, 軸方向 $m$ 次モード, 断面変形 $s$ 次モードに 対する減衰定数 $h_{m, s}$ を考慮すると, 式 (18) は以下の
ようになる。

$\ddot{\xi}_{m, s}+2 h_{m, s} \omega_{m, s} \dot{\xi}_{m, s}+\omega_{m, s}^{2}\left(1-\frac{\sigma_{0}+\sigma_{T} \cos \theta T}{\sigma_{m, s c r}}\right) \xi_{m, s}=0$

ここで, 静的応力 $\sigma_{0}$ が作用する場合の固有円振動 数

$$
\Omega_{m, s}=\omega_{m, s} \sqrt{1-\frac{\sigma_{0}}{\sigma_{m, s c r}}}
$$

と, 励振パラメータ

$$
\mu_{m, s}=\frac{1}{2} \cdot \frac{\sigma_{T}}{\sigma_{m, s c r}-\sigma_{0}}
$$

を用いて式 (24) を書き直す. その結果, 軸方向 $m$ 次 モード, 断面変形 $s$ 次モードに対する基準座標 $\xi_{m, s}$ に 関する運動方程式として次式が得られる.

$$
\ddot{\xi}_{m, s}+2 h_{m, s} \omega_{m, s} \xi_{m, s}+\Omega_{m, s}{ }^{2}\left(1-2 \mu_{m, s} \cos \theta T\right) \xi_{m, s}=0
$$

これはMathieu型方程式であり, Bolotin ${ }^{7)}$ が示したは り理論に基づく周期的圧縮荷重を受ける真直棒の曲 げ振動の動的不安定と同型の運動方程式である.

式 (27) より, 周期的軸力を受ける薄肉部材の局部 振動における安定領域と不安定領域の境界振動数は, 次の境界振動数方程式により近似的に求められる7). 主不安定領域 :

$$
\theta=2 \Omega_{m, s} \sqrt{1 \pm \sqrt{\mu_{m, s}{ }^{2}-4 \frac{\omega_{m, s}{ }^{2} h_{m, s}{ }^{2}}{\Omega_{m, s}{ }^{2}}}}
$$

副（第二）不安定領域：

$$
\theta=\Omega_{m, s} \sqrt{1-\mu_{m, s}{ }^{2} \pm \sqrt{\mu_{m, s}{ }^{4}-4 \frac{\omega_{m, s}{ }^{2} h_{m, s}{ }^{2}}{\Omega_{m, s}{ }^{2}}\left(1-\mu_{m, s}{ }^{2}\right)}}
$$

\section{3. 局部座屈特性と局部振動特性}

\section{(1) 解析の概要}

以下の具体的な解析においては, 代表的なトラス 部材である箱形断面と $\mathrm{H}$ 形断面（図-3）を解析モデ ルとし, 弾性を仮定した. 境界条件は両端ヒンジと し, 材料寸法および材料定数は以下の值を使用した.

$h=50.0 \mathrm{~cm}, \quad t_{f}=2.5 \mathrm{~cm}$ 弾性係数 $\quad E=206 \mathrm{Gpa}$

ポアソン比 $\quad \nu=0.3$ 


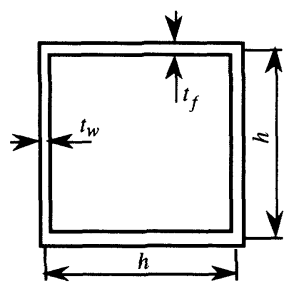

箱型断面

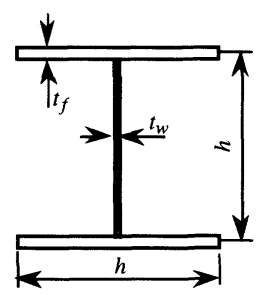

$\mathrm{H}$ 型断面
図-3 解析モデル

単位体積質量 $\rho=7850 \mathrm{~kg} / \mathrm{m}^{3}$

また, ウェブの板厚 $t_{w}$ はフランジの板厚 $t_{f}$ に対する比 が

$$
t_{w} / t_{f}=0.4, \quad 0.6,0.8
$$

と異なる 3 種類とした。

要素分割は, 箱形断面はフランジを 10 分割, ウェ ブを 10 分割, 合計 40 分割, H形断面はフランジを 10 分割, ウェブを 10 分割, 合計 30 分割とした.

図-3の断面について，式 (10), (11) を用いて座屈 解析ならびに固有振動解析を行い, 局部変形モード および座屈強度の特性について検討を行った. また, それぞれの断面において, 構成板要素相互の拘束の 影響を明らかにするためウェブだけを切り出した場 合との比較も行った. なお, 解析結果は, より一般性 を持たせるため部材長 $L$, 軸方向モード次数 $m$ の代わ りに, 座屈および固有振動の軸方向半波長 $l(=L / m)$ を用いて整理した。

\section{(2) 箱形部材}

図-4は, ウェブとフランジの板厚比 $t_{w} / t_{f}=0.4$ の箱 形部材について, 局部座屈および局部固有振動の軸 方向半波長 $l$ の枌高 $h$ に対する比 $l / h=0.5,1.0,6.0$ の ときの断面変形モード, 座屈応力 $\sigma_{s c r} I E$ おび固有円 振動数 $\omega_{s}$ をそれぞれ第 1 次から第 5 次まで示したも のである．2．で述べたとおり固有振動と座屈の断 面変形モードは一致しており, $l / h$ が大きくなるのに ともなって, 構成板要素だけの変形から構成板要素 が連成した変形，そして局部変形をともなった部材 全体の変形が生じるようになっている.いずれの断 面変形モードでも, 固有円振動数は軸方向半波長が 長くなるのにともなって小さくなっているが，座屈 応力は, 全体変形が生じる $l / h=6.0$ よりも局部変形に 支配される $l / h=0.5,1.0$ において小さなものとなって いる。

このような座屈強度と座屈の軸方向半波長との関 係は，断面変形 1 次モードにおいては図-5 のように なる. 縦軸は弾性係数 $E$ に対する座屈応力 $\sigma_{c r}$ の比 $\sigma_{c r}$ $I E$, 横軸は枌高 $h$ に対する軸方向半波長 $l$ の比 $l / / h$ で あり, 両対数目盛で示している. 実線, 点線および破 線はそれぞれウェブとフランジの板厚比 $t_{w} / t_{f}=0.4$,
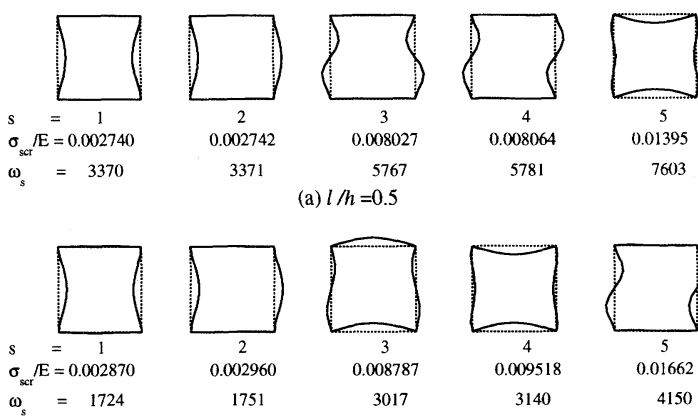

(a) $l / h=0.5$
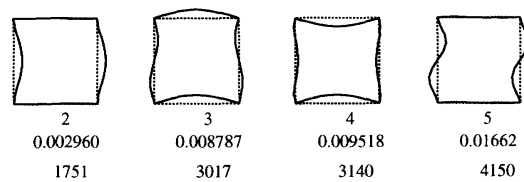

(b) $l / h=1.0$
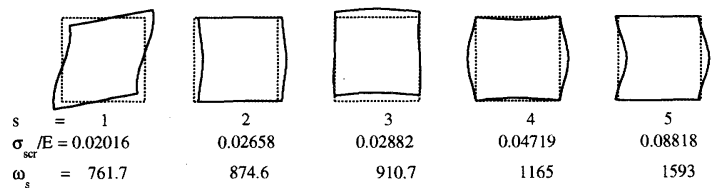

(c) $l / h=6.0$

図 -4 箱形部材の座屈および固有振動の 断面変形モ一ド $\left(t_{w} / t_{f}=0.4\right)$

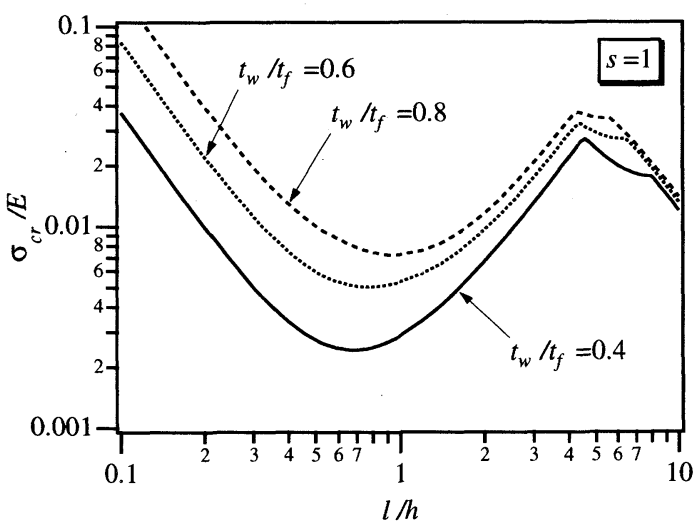

図-5 箱形部材の座屈応力と軸方向半波長の関係

0.6, 0.8 の箱形部材の局部座屈強度を表す. 座屈曲線 は, いずれの断面でも軸方向半波長の増大にとも なって減少し, $l / h=1$ 程度で極小值を示した後増加し て, $l / h>4.0$ で再び減少している. 図-4のモード図 より, $l / h<4.0$ の範囲が局部座屈領域であることがわ かる. $t_{w} / t_{f}$ が小さいほど局部座屈荷重は小さく, 最小 座屈応力を与える $l / h$ は $t_{w} / t_{f}$ が大きくなるにともなっ て長くなっているがいずれも $l / h<1.0$ である.

図-6は，ウェブとフランジの板厚比 $t_{w} / t_{f}=0.4,0.8$ の箱形部材とウェブだけを切り取った場合の局部座 屈強度を断面変形 1 次モードについて比較したもの である. 切り取ったウェブの境界条件は，周期的応 力が作用する辺はヒンジとし，フランジとの接合辺 をヒンジと固定の 2 種類とした. 実線は箱形部材の 座屈曲線, 点線および破線は切り出したウェブの座 屈曲線であり, それぞれフランジとの接合辺が固定, およびヒンジの場合を表す．ウェブと箱形部材の局 部座屈応力は, $l / h$ が小い範囲ではほぼ一致してい 


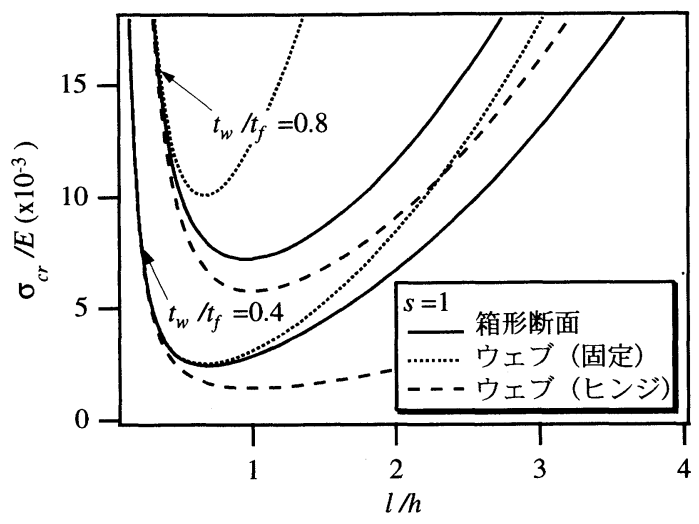

図-6 切り取ったウェブと箱形部材の座屈強度の比較

るが, l/hが大きくなるにともなって差は大きくな り, $t_{w} / t_{f}$ が大きいほどウェブだけで近似できる $l / h$ の 範囲は小さくなっている. $t_{w} / t_{f}=0.4$ の箱形部材の最小 座屈応力はフランジとの接合辺を固定としたウェブ の最小座屈応力とほぼ一致し, $t_{w} / t_{f}=0.8$ の場合にはフ ランジとの接合辺をヒンジとしたウェブの最小座屈 応力に近い值となっている.

\section{(3) $\mathrm{H}$ 形部材}

箱形部材と同様の検討を $\mathrm{H}$ 形部材についても行っ た．結果の一部を図-7〜図-9に示す.

図-7は, ウェブとフランジの板厚比 $t_{w} / t_{f}=0.4$ の H 形部材について, 局部座屈および局部固有振動の軸 方向半波長 $l$ の析高 $h$ に対する比 $l / h=0.5,1.0,6.0$ の ときの断面変形モード, 座屈応力および固有円振動 数を示したものである. $l / h=0.5$ の第 1 , 第 2 , 第 5 次モード, および $l / h=1.0$ の第 4 , 第 5 次モードでは ウェブあるいはフランジだけに変形が生じているが, その他のモードではウェブとフランジが連成した変 形を示している. また, $l / h=6.0$ の第 3 , 第 5 次モ一 ドにおいては, 局部変形だけでなくはりとしての全 体変形も生じている.

$\mathrm{H}$ 形部材の断面変形第 1 次モードにおける座屈強 度と座屈の軸方向半波長との関係を図-8に示す. 縦 軸は弾性定数 $E$ に対する座屈応力 $\sigma_{c r}$ の比 $\sigma_{c r} / E$, 横軸 は枌高 $h$ に対する軸方向半波長 $l$ の比 $V / h$ を両対数目 盛で表し, 実線, 点線および破線はそれぞれウェブ とフランジの板厚比 $t_{w} / t_{f}=0.4,0.6,0.8$ の 形部材の 座屈強度を表す. $t_{w} / t_{f}=0.4$ の座屈曲線は 2 個の極小值 を有し, $l / h \fallingdotseq 0.7$ で最小局部座屈応力を示している. $t_{w} t_{f}=0.6$ の座屈曲線も 2 個の極小值を有するが, 局部 座屈応力が最小になるのは $l / h \fallingdotseq 2.0$ であり,$t_{w} / t_{f}=0.4$ の場合の 2 倍以上となっている. 一方, $t_{w} / t_{f}=0.8$ では 極小値は 1 個となり, $l / h \fallingdotseq 1.7$ と $t_{w} / t_{f}=0.6$ の場合よ りも短くなっている. 図-7より, H 形部材の局部座

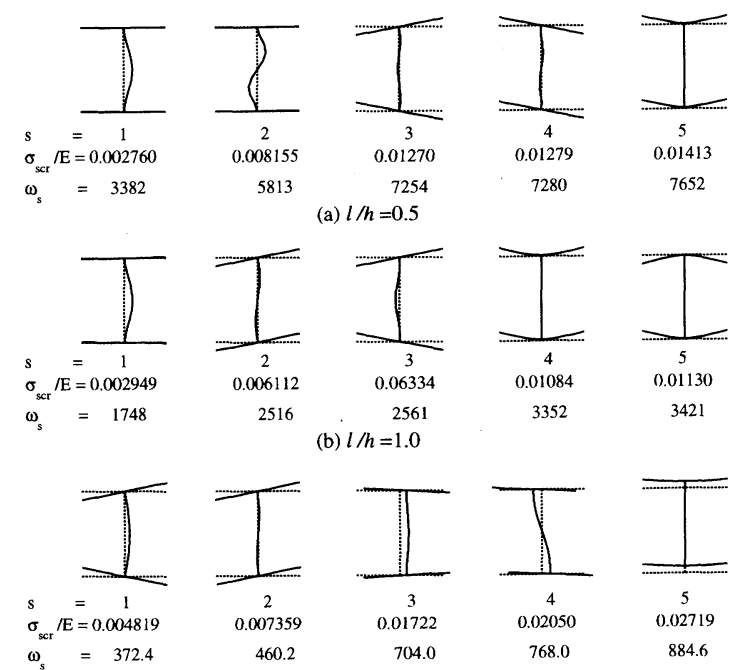

(c) $l / h=6.0$

図-7 H 形部材の座屈および固有振動の 断面変形モード $\left(t_{w} / t_{f}=0.4\right)$

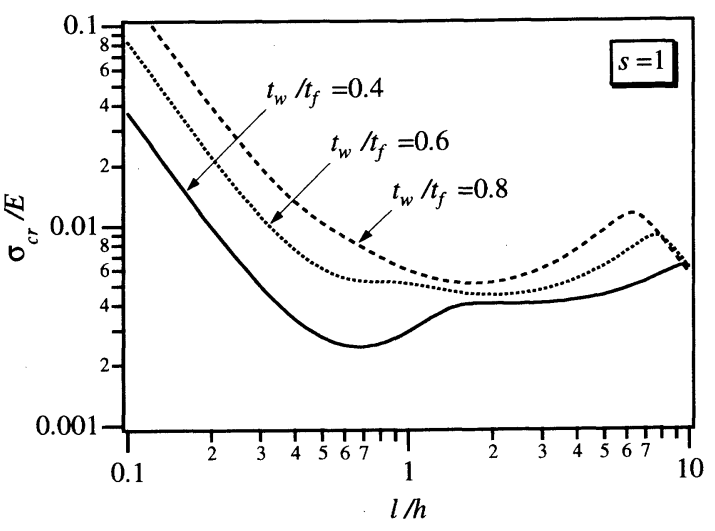

図-8 H 形部材の座屈応力と軸方向半波長の関係

屈の断面変形 1 次モードは軸方向半波長が大きくな るのにともなってウェブのみが面外に変形したモー ドからウェブの面外変形とフランジのねじり変形が 連成したモードに変化するが, $t_{w} / t_{f}$ が大きくなると ウェブのみが変形するモードは生じにくくなり, 最 小座屈時の断面変形モードはウェブの面外変形とフ ランジのねじり変形が連成したモードとなることが 推測される.

図-9は, ウェブとフランジの板厚比 $t_{w} / t_{f}=0.4,0.8$ の $\mathrm{H}$ 形部材の断面変形 1 次モードの座届強度につい て, ウェブだけを切り取った場合との比較を示した ものである. ウェブの境界条件は箱形部材との比較 に用いたものと同じ 2 種類である. 実線が $\mathrm{H}$ 形部材 の座屈曲線, 点線および破線が切り出したウェブの 座屈曲線であり, それぞれフランジとの接合辺が固

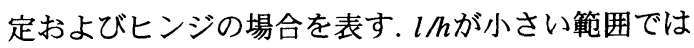
ウェブと $\mathrm{H}$ 形部材の座屈強度はほぼ一致するが, $t_{w}{ }^{\prime}$ 


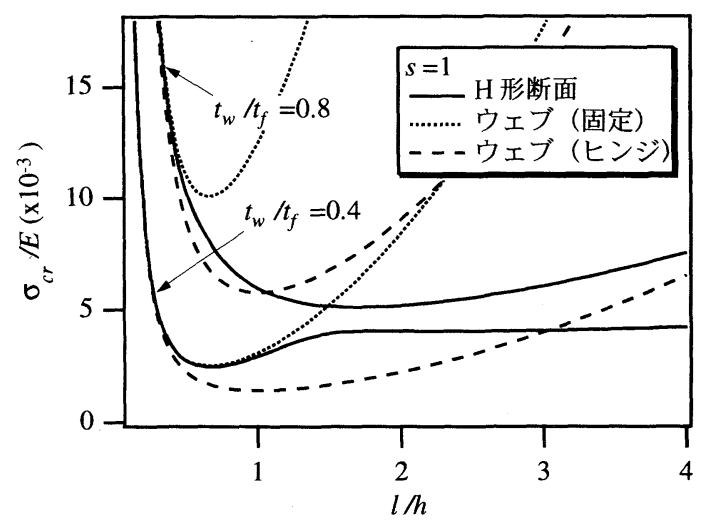

図-9 切り取ったウェブとH形部材の座屈強度の比較

$t_{f}$ が小さい方が連成座屈を示す $l / h$ は大き,$t_{w} / t_{f}=0.4$ の最小座屈応力はフランジとの接合辺を固定とした ウェブとほぼ一致している. $l / h$ が大きくなると H形 部材の局部座屈強度は低下してフランジとの接合辺 をヒンジとしたウェブよりも小さな座屈応力を示し, $t_{w} / t_{f}=0.8$ の最小座屈応力は構成板要素が連成した局部 座屈に支配されていることがわかる.

\section{4. 局部振動の不安定特性}

以下では，図-3に示した解析モデルについて，局 部振動の不安定特性を検討する。これにより, 動的 不安定に陥りやすい外力周期，および動的不安定に 対して有効なダイヤフラムや補剛材の位置等を明ら かにすることができる.

2. より, 軸方向 $m$ 次モード, 断面変形 $s$ 次モード に対する主不安定領域および副（第二）不安定領域 の境界振動数は式 (28), (29) を用いて求めることが でき, その結果は図-10のようになる. 縱軸は励振パ ラメータ $\mu_{m, s}$ であり, 横軸は周期的応力の円振動数 $\theta$ を部材の第 $s$ 次固有円振動数 $\Omega_{m, s}$ の 2 倍で無次元化し て表している. 実線が減衰定数 $h_{m, s}=0.03$, 点線が減 衰 $h_{m, s}=0.00$ としたときの境界振動数であり, 斜線を 施した部分が減衰定数 $h_{m, s}=0.03$ のときの不安定領域 を表す。

主不安定領域は $\theta / 2 \Omega_{m, s}=1$, 副（第二）不安定領域 は $\theta / 2 \Omega_{m, s}=0.5$ の付近に生じ, 励振パラメータ $\mu_{m, s}$ が 大きくなるほど不安定領域は広くなっている.これ はよく知られている単純励振型振動の動的不安定領 域の図である. 2. で示したように, 固有モードと座 届モードが一致する部材の局部振動の不安定領域は, 縦軸および横軸をこれらの無次元量で表すことによ り, 断面形, 断面寸法, 軸方向モード次数, 断面変形 モード次数に関係なく図-10で表すことができる.

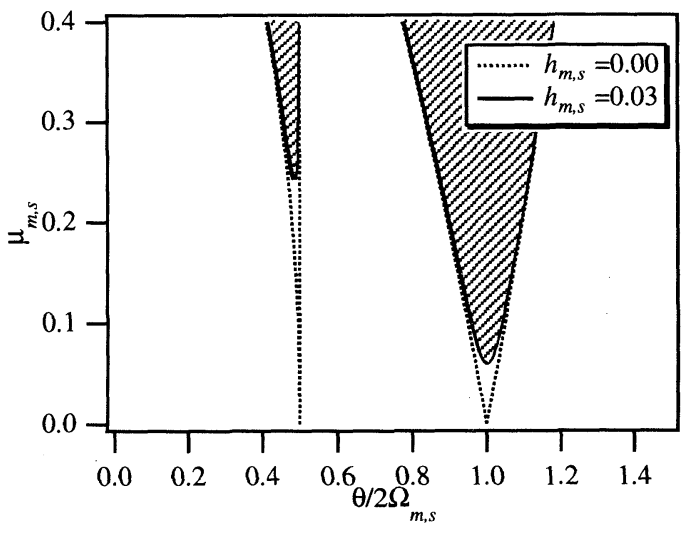

図 -10 動的不安定領域

しかしながら,図-10のような動的不安定領域の表 示はそれぞれのモードの不安定特性を示すことはで きるが, 一部材に生じる軸方向モードと断面変形 モードが組み合わさった様々な局部振動について不 安定特性の違いを比較・検討することができない. そこで, 断面変形モード次数を固定して軸方向モ一 ド次数を変化させた場合の局部振動モードについて, 周期的応力の振幅 $\sigma_{T}$, 静的応力 $\sigma_{0}$ を共通の值として 境界振動数を求め, 不安定特性の違いを明確にする ことを試みた。

以下に，その具体的な数值計算の一例として断面 変形モード次数 1 の場合を示す. 3.の解析では, 一 般性を持たせるために局部振動の軸方向半波長に着 目していたが,ここでは, 薄肉部材の部材長が与え られた場合について局部振動の安定性の検討を行う.

図-11は, 枌高に対する部材長の比 $L / h=5.0$ の箱形 部材および $\mathrm{H}$ 形部材に静的応力 $\sigma_{0}=0$, 周期的応力 $\sigma_{T}$ $/ E=0.001$ が作用した場合の局部振動の不安定領域に ついて, 軸方向モード次数 $m$ による違いを比較した ものである.なお,ここでは減衰は無視している. 横 軸は軸方向 $m$ 次モード $(m=1,2,3, \cdots)$ のときの軸 方向半波長 $l(=L / m)$ を桁高 $h$ で無次元化したもので あり，縦軸はそれぞれのモードにおける固有円振動 数 $\Omega_{m, 1}$ の 2 倍に対する周期的応力の円振動数 $\theta$ の比 $\theta$ $12 \Omega_{m, 1}$ で表し, 片対数目盛で示している. また,

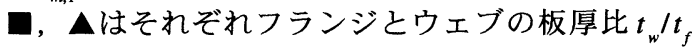
$=0.4,0.6,0.8$ の断面の境界振動数を表し, 軸方向 モード次数に対応した軸方向半波長の位置にプロッ トした 2 個の同記号に挟まれた部分が不安定領域と なる.

不安定領域の幅が最も広くなるのは, 箱形部材で はいずれ断面でも軸方向モード次数 $m>5$ すなわち $l /$ $h<1.0$ であるが, H形部材ではフランジとウェブの板 厚比によって $l / h$ の值に 2 倍以上の差が生じ, $t_{w} / t_{f}$ $=0.4$ の断面で $l / h \fallingdotseq 0.6 \sim 0.7(m=7), t_{w} / t_{f}=0.6$ の断面 


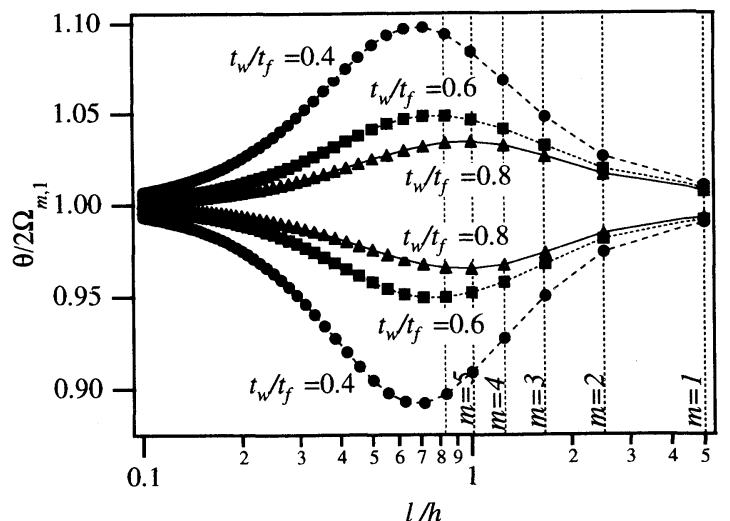

(a) 箱形部材

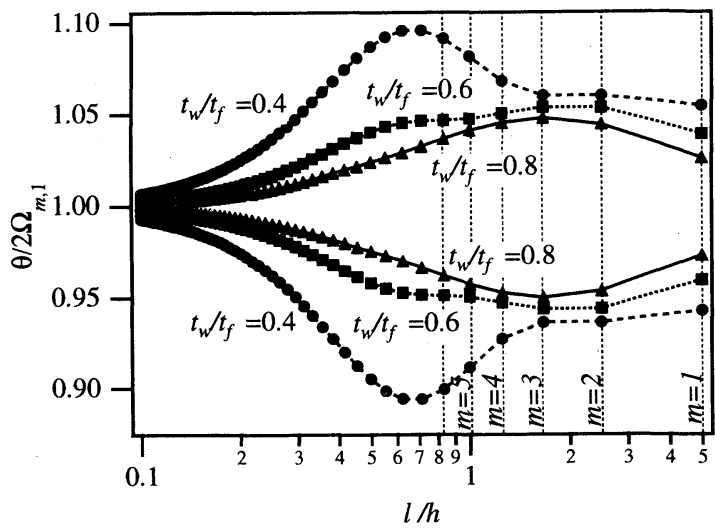

(b) $\mathrm{H}$ 形部材

図-11 主不安定領域と軸方向半波長の関係 $\left(L / h=5.0, \sigma_{T} / E=0.001, \sigma_{0}=0.0\right)$

では $l / h=2.5(m=2), t_{w} / t_{f}=0.8$ の断面では $l / h \fallingdotseq 1.7(m$ =3) となっている. 図 -5 , 図 -8 と比較すると, 局部座 屈応力が小さい軸方向モードで不安定領域の幅は広 くなっていることがわかる.

図 -11における不安定領域の幅は係数励振型振動 を生じる軸圧縮力の円振動数の範囲をそれぞれの局 部振動の固有円振動数で無次元化したものであり, 不安定領域の幅が広いモードほど局部振動が発生し やすいことを意味している. したがって，ダイヤフ ラムや補剛材の位置決定に際してこれらの值を考慮 することにより局部振動の発生を抑えることが可能 となる。

図-11 (a) より $t_{w} / t_{f}=0.8$ の箱形部材において局部振 動の不安定領域の幅が最大となるときの部材中央断 面の断面変形モード，ならびにウェブおよびフラン ジの右半分の等高線図を図-12に示す. ウェブだけで なくフランジにも面外変形が生じ, 軸方向 5 次モ一 ドの変形であることがわかる.

図 -13 は, $t_{w} / t_{f}=0.4$ の箱形部材に静的応力 $\sigma_{0}=0$, 周

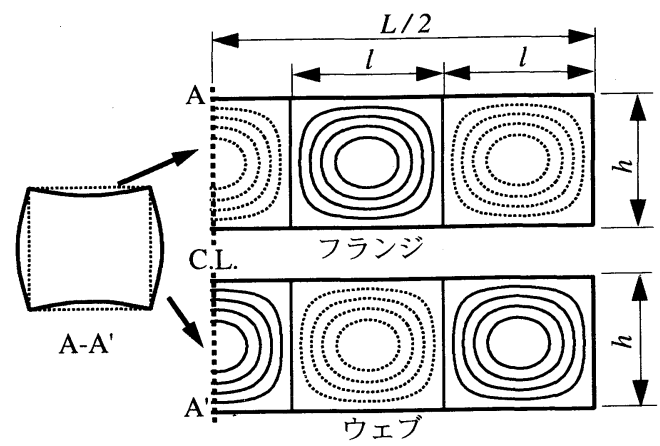

— : 凸 …... : ๒

図-12 箱形部材の最大不安定領域の振動モード $\left(t_{w} / t_{f}=0.8, \sigma_{T} / E=0.001, \sigma_{0}=0.0\right)$

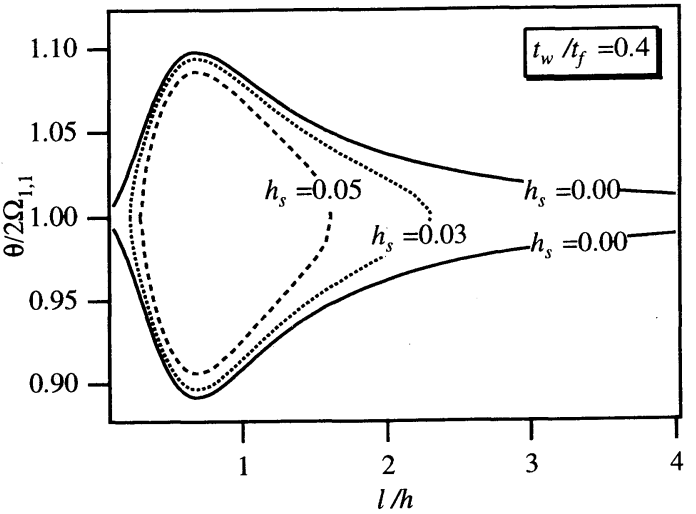

図-13 箱形部材の主不安定領域に対する減衰の影響 $\left(\sigma_{T} / E=0.001, \sigma_{0}=0.0\right)$

期的応力 $\sigma_{T} / E=0.001$ が作用したときの主不安定領 域に対する減衰の影響を示す．横軸は枌高に対する 軸方向半波長の比 $l / h$, 縦軸はそれぞれのモードにお ける第 1 次固有円振動数 $\Omega_{1,1}$ の 2 倍に対する周期的 応力の円振動数 $\theta$ の比 $\theta / 2 \Omega_{1,1}$ で表している. なお, こ こでは部材長は限定していない. 実線, 点線および 鎖線は，それぞれ減衰定数 $h_{s}=0.00,0.03,0.05$ のと きの境界振動数を表し，同じ線種の曲線で囲まれた 部分が不安定領域に相当する. 減衰を考慮すると, 局部座屈応力が小さく不安定領域の幅が広いモード では減衰定数が大きくなるのにともなって不安定領 域は狭くなり, 動的不安定領域の生じる $l / h$ の範囲は 狭くなっている. 局部座屈応力が大きく不安定領域 の幅が狭いモードでは不安定領域の幅が消失し, 動 的な不安定は生じなくなっている.

続いて, 部材を構成する板要素の連成振動の影響 について明らかにするため, ウェブのみを切り取つ て解析した場合との比較を行った。図-14 は, $t_{w} / t_{f}$ $=0.8$ の箱形部材および $\mathrm{H}$ 形部材の局部振動の主不安 定領域とウェブだけの場合の主不安定領域を比較し たものである. 静的応力 $\sigma_{0}=0$, 周期的応力 $\sigma_{T} / E$ 


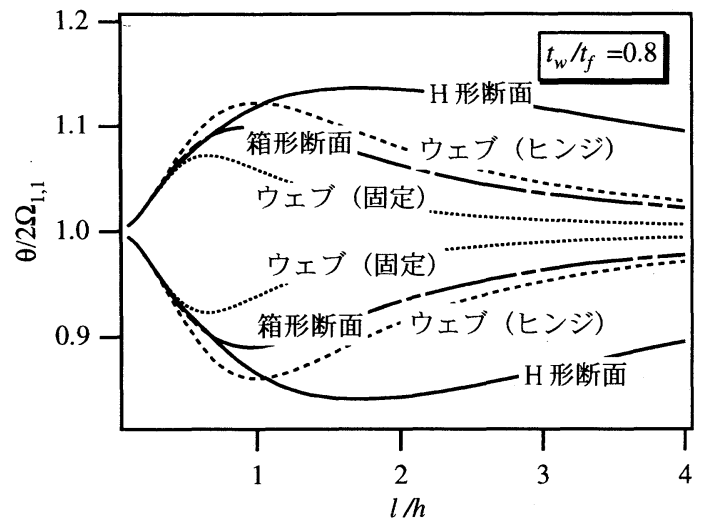

図-14切り取つたウェブと薄肉部材の動的不安定領域 の比較 $\left(\sigma_{T} / E=0.002, \sigma_{0}=0.0, h_{1,1}=0.0\right)$

$=0.003$ を作用させ, 軸方向モード次数 $m=1$, 断面変形 モード次数 $s=1$ としている. 実線は $\mathrm{H}$ 形部材, 一点鎖 線は箱形部材の境界振動数, 点線および破線はそれ ぞれフランジとの接合辺が固定およびヒンジの場合 のウェブの境界振動数を表す. 図-6,9の結果と同様 に, $l / h<0.5$ ではウェブと各断面の境界振動数はほぼ 一致するが, $l / h>0.5$ で差が生じている. 特に, H形 部材では不安定領域の最大幅がフランジとの接合辺 をヒンジとしたウェブの約 1.5 倍となり, そのときの 軸方向半波長も長くなっている.これにより, フラン ジに対して限定的な扱いをしている従来の動的不安 定領域の評価は妥当でなく, 薄肉断面全体を対象之 して局部振動を考慮した動的安定性の検討が必要で あることがわかる。

トラス構造において H 形部材は引張部材に使用さ れることから, H形部材の主不安定領域に及ぼす静的 応力の影響についても検討を行った. 図-15は, $t_{w} / t_{f}$ $=0.6$ の $\mathrm{H}$ 形部材について, 周期的応力 $\sigma_{T} / E=0.002$ と 乙, 静的応力を $\sigma_{0} / E=0.000,-0.002,-0.005$ と変化 させた場合を示したものである. 縦軸は周期的軸力 の円振動数 $\theta$ を静的応力 $\sigma_{0}$ が作用する場合の固有円 振動数 $\Omega$ の 2 倍で無次元化している. 不安定領域の 幅は, 静的引張応力が大きくなるほど狭くなるが, 軸 方向半波長の変化による差は少なくなっている. ま た, 静的応力と周期的応力の和が引張応力となって 圧縮応力が生じない場合でも不安定領域は生じるこ とがわかる.

\section{5. まとめ}

周期的軸力が作用するトラス部材における局部振 動の不安定性を解明するため, 両端ヒンジの箱形部 材および $\mathrm{H}$ 形部材について, 動的不安定の基本因子

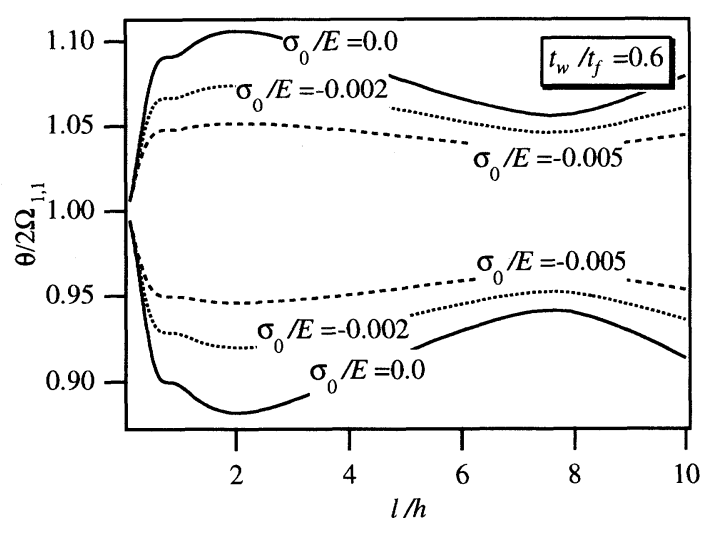

図-15 H 形部材の主不安定領域に及ぼす静的応力の 影響 $\left(\sigma_{T} / E=0.002, h_{1,1}=0.0\right)$

である固有振動特性および局部座屈特性を明らかに した. 次いで, それらの特性を踏まえて, 周期的軸力 が作用する両端ヒンジの箱形部材および $\mathrm{H}$ 形部材の 局部振動の不安定現象を解析し, その特性を検討し た. その結果，以下のことが明らかになった.

1) 座屈と固有振動の断面変形モードは一致し, 動 的不安定問題における運動方程式はすべてのモード について独立なMathieu方程式で表現することができ る.これにより, 局部振動の不安定領域は縦軸・横軸 を適当な無次元量に取ることにより部材長, 断面形, モード次数に関係なく同一の図で表すことができる.

2) 局部振動の不安定領域は, 局部座屈強度が極小 值を示すモードで最も広くなる. 断面変形モード次 数を 1 とした場合, 局部振動の不安定領域の幅が最 も広くなる軸方向モードは, 箱形部材では枌高に対 する軸方向半波長の比 $l / h$ が 0.7 から 1 のモードであ る. また, H形部材では, フランジに対するウェブの 板厚比 $t_{w} / t_{f}$ によって最大不安定領域幅を生じる軸方向 半波長は異なり, $t_{w} / t_{f}$ が 0.6 以上の断面では $l / h$ が 1.7 以上のモードで局部振動の不安定領域の幅は最大と なる.

3）ウェブだけを取り出した場合の動的不安定解析 は, $l / h$ が 0.5 以下のモードの局部振動の不安定領域 に適用でき, $t_{w} / t_{f}$ が大きいほど適用できる $l / h$ は小さ くなる. また, フランジとの接合辺をヒンジとした ウェブの動的不安定領域は, 箱形部材については過 大評価, $\mathrm{H}$ 形部材については過小評価となる.

\section{参考文献}

1) 八巻昇, 永井健一: 周期的圧縮荷重をうける矩形板の動 的安定, 東北大学高速力学研究所報告, 第 36 巻, 第 351 号, pp.147-168, 1975 年. 
2) 高橋和雄, 田川賢, 池田虎彦, 松川徹 : 面内曲げを受け る長方形板の動的安定性, 土木学会論文報告集, 第 341 号, pp.179-186，1984 年 1 月.

3) Takahashi, K., Konishi, Y., Ikeda, T. and Kawano, R. : Nonlinear Response of a Rectangular Plate Subjected to Inplane Dynamic Moment, Proc. of JSCE, No.374/I-6, pp.79-87, Oct. 1986.

4) 高橋和雄, 池田虎彦, 川野隆太 : 幾何学的非線形性を考 慮した面内変動曲げを受ける長方形板の動的安定性, 構 造工学論文集, Vol.32A, pp.705-714，1986 年 3 月.

5) 高橋和雄, 小西保則, 川野隆太, 浦河茂男 : 面内変動曲 げを受ける初期変形をもつ長方形板の動的安定性, 構造 工学論文集, Vol.33A, pp.485-494，1987 年 3 月.

6) Kuranishi, S., Fukaya, S. and Shima, T. : Vibration of an Ini- tially Deflected Web Plate under Periodic Beam Bending, Proc.of JSCE, No.341, pp.229-232, Jan. 1984.

7) Bolotin, V. V. : 弾性系の動的安定, コロナ社, 1972 年.

8) Brown, J. E., Hutt, J. M. and Salama, A. E. : Finite Element Solution to Dynamic Stability of Bars, AIAA Journal, Vol.6, pp.1423-1425, Jul. 1968.

9) Hutt, J. M. and Salam, A. E. : Dynamic Stability of Plates by Finite Elements, Journal of the Engineering Mechanics Division, ASCE, Vol.97, EM3, pp.879-899, Jun. 1971.

10) 大越康史, 三上隆, 芳村仁: 周期的荷重を受ける I 形断 面材の動的安定, 土木学会第38回年次学術講演会講演概 要集, pp.178-179, 1983 年.

(1996.12.10 受付)

\title{
DYNAMIC INSTABILITY OF LOCAL VIBRATION OF THE THIN-WALLED MEMBERS UNDER PERIODIC AXIAL LOADS
}

\author{
Miyoshi OKAMURA and Yasuharu FUKASAWA
}

\begin{abstract}
The dynamic instability of local vibration of the simple supported thin-walled members under periodic axial loads is investigated by applying the finite strip method. At first, the analyses of the local buckling and the free vibration of the members are carried out and the characteristics of them are discussed. Secondly, the unstable regions of local vibration of the members under various geometrical parameters are calculated and the effects of the some factors which control the dynamic instability phenomena are clarified. Based on these results, the most efficient dispositions of diaphragm or stiffener are mentioned.
\end{abstract}

